\title{
Clinical Reasoning: A 16-year-old boy with progressive cognitive decline and gait impairment
}

Qing Ke, MD, PhD, * Xiaoyan Liu, MD, * Kang Wang, MD, PhD, Zhongqin Chen, MD, Ming Liu, MS, Xiaohua Ma, BS, Lihua Yu, MD, PhD, and Benyan Luo, MD, PhD

Neurology ${ }^{\circledR}$ 2020;94:449-454. doi:10.1212/WNL.0000000000009062
Correspondence

Dr. Luo

luobenyan@zju.edu.cn

\section{Section 1}

A 16-year-old boy was admitted to our department primarily due to rapidly progressive cognitive decline and gait impairment for 1 month. Because of his vision loss, gait impairment, vague speech, choking, hearing loss, globally slowed response, and childish performance, which appeared successively and developed gradually, he became unable to continue daily activities over the prior 1 month.

In the past, the patient had a recurrent rash that started in the neonatal period and progressed to include his scalp, extremities, and trunk (figure, A). He was delivered at full term but presented with a short stature and poor weight gain 4 years ago, while his daily activities were unlimited.

Physical examination revealed a height of $130 \mathrm{~cm}$, a weight of $28 \mathrm{~kg}$, permanent tooth loss, scant and dry hair, segments of rash all over the body, pus flowing along the external auditory canal, and pulmonary moist rales. Upon neurologic examination, the patient had dysarthria and intellectual deterioration, yielding a Mini-Mental State Examination score of 1/30. A cranial nerve examination revealed impaired vision and hearing, horizontal nystagmus, right central facial and tongue paralysis, and poor bilateral pharyngeal reflexes. The patient exhibited a muscle strength of $4 / 5$, increased tone, deep tendon reflexes of $4+$ in all extremities, and a positive bilateral Babinski sign. He swayed when opening and closing his eyes in the Romberg test, was unable to walk straight, and exhibited a wide-based gait.

\section{Questions for consideration:}

1. Where was the patient's condition localized?

2. What is the appropriate diagnostic framework and initial approach to this investigation?

\footnotetext{
*These authors contributed equally to this work.
}

From the Department of Neurology (Q.K., X.L., K.W., Z.C., L.Y., B.L.), The First Affiliated Hospital, College of Medicine, Zhejiang University; Department of Neurology (M.L.), Shulan (Hangzhou) Hospital, Hangzhou; and Department of Neurology (X.M.), The Second Division of Xinjiang Production and Construction Corps, Korla Hospital, China.

Go to Neurology.org/N for full disclosures. Funding information and disclosures deemed relevant by the authors, if any, are provided at the end of the article. 
Figure Photograph and brain MRI of the patient and Sanger sequencing of the patient and his parents
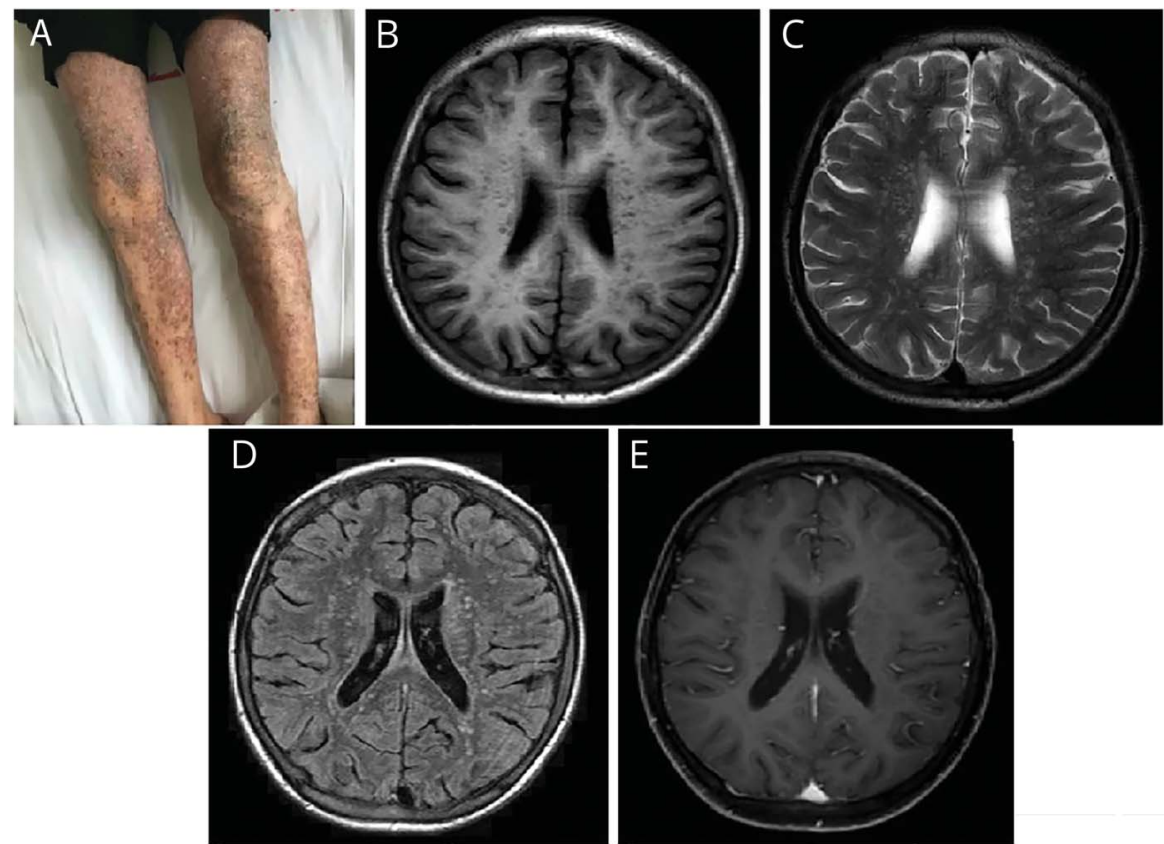

Mutation in DOCK8 c.3152delG

Mutation in DOCK8 c.5175G>C

F

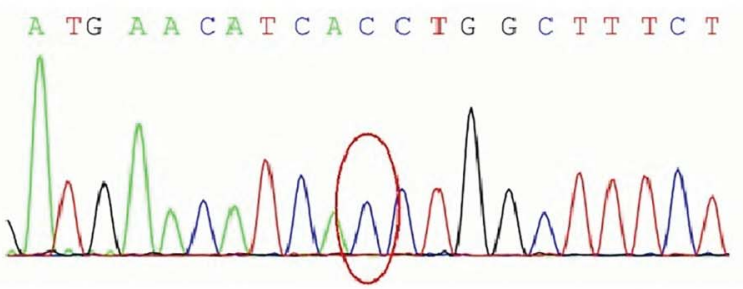

A C T T CAC C G A CAG TG G C C T G G

G
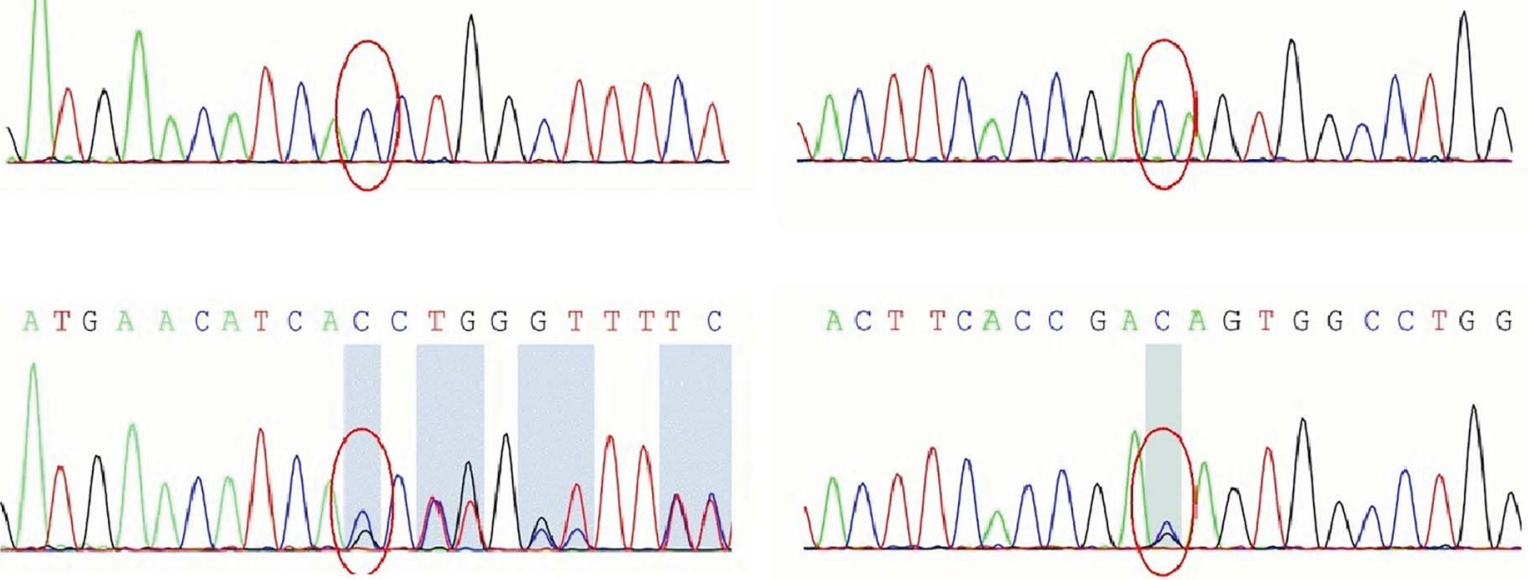

$A C T T C A C C G A C A G T G G C C T G G$

$\mathrm{H}$

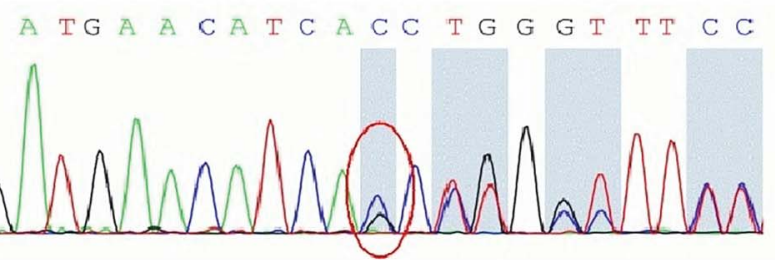

A C T T T A C C G A C A G T G G C C T G G

(A) Recurrent rash. Brain MRI detected multifocal lesions affecting white matter, specifically revealing low signals in T1-weighted imaging (B) and high signals in T2-weighted imaging $(C)$ and T2-weighted fluid-attenuated inversion recovery sequence (D), but no enhancement (E). The patient (F) had homozygous mutations in DOCK8 (c.3152delG and c.5175G>C). Both his mother (G) and father (H) showed heterozygous mutations in DOCK8 (c.3152delG and c.5175G>C).

GO TO SECTION 2 


\section{Section 2}

The observed intellectual decline was suggestive of cerebral cortex or hemisphere involvement. The visual and auditory pathway, left corticobulbar tracts, bilateral pyramidal tracts above the level of cervical enlargement, and cerebellum were also involved, given the patient's cranial nerves, motor system, and coordination performances. The patient's presentation was suggestive of a multifocal process specifically localized in the extensive cerebral cortical or subcortical areas, the cerebellum, and the brainstem.

Considering the patient's chief complaints that emerged over the past 1 month, we approached this case as an acquired disease. Based on the cognitive decline, his condition was likely related to viral encephalitis (such as herpes simplex virus encephalitis, subacute sclerosing panencephalitis, progressive multifocal leukoencephalopathy, or cytomegalovirus [CMV] encephalitis), a cerebral parasitic infection (such as cysticercosis, schistosomiasis, paragonimiasis, or malaria), a demyelinating or inflammatory disease (such as neuromyelitis optica spectrum disease or multiple sclerosis), a metabolic disease (such as electrolyte imbalance), or a tumorous process (such as germinoma). Moreover, his characteristic features of scant and dry hair, recurrent rash, and arrested development indicated the possibility of an inherited disorder, such as phenylketonuria or biotinidase deficiency. The above etiologies were explored with a workup that mainly included a neuroimaging study involving cranial and spinal T1, T2, diffusionweighted, and enhanced MRI; a CSF test involving pressure, routine tests, and biochemistry indicators; a demyelinating panel involving assays for serum and CSF myelin oligodendrocyte glycoprotein, myelin basic protein, flotillin-1 and -2, and aquaporin-4 immunoglobulin $\mathrm{G}$ ( $\mathrm{IgG}$ ) antibodies, oligoclonal bands, and IgG index; serum and urine mass spectrometry analysis; and metabolic measures of vitamin $B_{12}$, folate, lactic acid, ceruloplasmin, ammonia, homocysteine, thyroid function, and biotinidase.

Initial standard examinations showed elevated eosinophilia level (24.2\%) and normal electrolyte, renal, liver, and creatine kinase levels. Tumor screening suggested slightly elevated levels of carcinoembryonic antigen and carbohydrate antigen 199. MRI scans (figure, B-E) revealed multiple lesions localized to the bilateral cerebral hemisphere, cerebellum, brainstem, and spinal cord that appeared as mainly infiltrative white matter. A lumbar puncture showed a CSF pressure of $85 \mathrm{~mm} \mathrm{H}_{2} \mathrm{O}, 75$ white cells, a lymphocyte proportion of $75 \%$, a glucose level of $2.09 \mathrm{mmol} /$ $\mathrm{L}$, a chlorine level of $122 \mathrm{mmol} / \mathrm{L}$, and a protein level of $0.99 \mathrm{~g} /$ L. Analyses of metabolic measures indicated an elevated level of only homocysteine; the demyelinating panel and mass spectrometry results were negative. In parallel, ophthalmic and otologic testing indicated macular atrophy, scleritis, vitreous opacities, and chronic suppurative otitis media.

\section{Questions for consideration:}

1. Based on these findings, what would be your diagnosis at this stage?

2. What further workup would you order?

\section{GO TO SECTION 3}




\section{Section 3}

The CSF and MRI findings were suggestive of an encephalitis. Therefore, we moved toward exploring the patient's pathogenic features. The combination of elevated serum eosinophilia indicated the possibility of parasitic infection, but serum and CSF parasite IgG antibodies, including hydatid, Angiostrongylus cantonensis, cysticercus, cysticercosis, paragonimiasis, sparganum, Schistosoma japonicum, toxoplasma, and liver fluke, were all absent. In addition, CSF Epstein-Barr virus and JC virus DNA, serum HIV and syphilis antibodies, a T-cell spot test for Mycobacterium tuberculosis, and the latex agglutination test for the Cryptococcus capsular antigen were negative.
Simultaneously, the FilmArray meningitis/encephalitis panel was negative for 13 pathogens and positive for CMV from CSF. After integrating the patient's clinical manifestations, fluorescence quantitative PCR array was applied to detect CMV DNA in samples of CSF, serum, urine, and external auditory canal secretions, and all of these test results were positive, while the CSF profile revealed 10,000 copies. CMV immunoglobulin M (IgM) and IgG antibodies from CSF were also positive.

\section{Questions for consideration:}

1. What further investigation would you order to explore the underlying etiology?

2. What would be your final diagnosis?

GO TO SECTION 4 


\section{Section 4}

Based on the increased CMV DNA copy numbers in the CSF, serum, urine, and external auditory canal secretions, an acquired CMV infection was likely the cause of the patient's decline over the last month. CMV is one of the most common origins of viral congenital infection, with the majority of affected individuals being asymptomatic. CMV infection can manifest in a variety of ways, ${ }^{1}$ especially in immunocompromised patients.

Simultaneous with other tests, the patient had extremely high serum eosinophil levels, an etiology considered to reflect an allergic disease, a parasitic infection, a hematologic or neoplastic disorder, or an immunologic disease. Bone marrow puncture was carried out but did not reveal any abnormal hematologic manifestations, and leukocyte fusion genotyping, immunophenotyping of bone marrow, and CSF immunoblotting were all normal. A skin biopsy revealed chronic dermatitis. In view of the above investigations and considering the CMV infection, the origin of the high serum eosinophil levels observed in this patient possibly reflects an immunodeficiency disease.

The next question was whether the immunodeficiency disorder was acquired or primary. With regard to the former, no longterm steroid or immunosuppressor, post-transplantation, or serum HIV antibodies were exhibited. Hence the patient's diagnosis was more likely attributable to the latter, which can be classified into 9 phenotypes. ${ }^{2}$ In this regard, serum measures suggested an increased immunoglobulin E (IgE) level of 3,698 $\mathrm{IU} / \mathrm{mL}$, a slightly decreased IgM level, normal immunoglobulin A and IgG levels, slightly decreased CD3+ T cells level, slightly increased CD19+ B cells level, normal natural killer cells level, and a normal antinuclear antibody profile. When the patient's clinical manifestations were combined with the level of carcinoembryonic antigen and carbohydrate antigen 199, eosinophils, and IgE, a diagnosis of hyperimmunoglobulin $\mathrm{E}$ syndrome (HIES) was suspected. A genetic analysis confirmed homozygous mutations in the dedicator of cytokinesis 8 (DOCK8) gene (c.3152delG and c.5175G>C). Gene validation further identified heterozygous mutations of the 2 loci in his father and mother (figure, F-H). Ultimately, the definitive diagnosis was HIES due to DOCK8 mutations. Despite active antiviral therapy, the patient died of infection after 2 months.

\section{Discussion}

HIES is a rare primary immunodeficiency disorder characterized by eczema, recurrent infection, and extremely high levels of serum IgE. Various genetic etiologies of this condition have distinct clinical features. ${ }^{3}$ DOCK8 genetic mutations, which have been shown to be correlated with autosomal recessive modes of inheritance, cause susceptibility to serious cutaneous viral infections, atopic condition, and a predisposition to malignancies. ${ }^{4}$

Accordingly, intracranial viral infection in an immunocompromised patient could present as a subacute onset with single or multiple pathogens, with CMV, herpes simplex virus, and varicella-zoster virus commonly being implicated, and could induce meningitis, encephalitis, and myelitis associated with CMV, Epstein-Barr virus, and others in patients with HIES due to DOCK8 mutations. ${ }^{5-7}$ The brain abnormalities associated with HIES have not been well-established, although a few relevant studies have been performed, mainly in patients involving infection. ${ }^{8}$ Other studies have also shown that focal hyperintensities, Chiari 1 malformations, lacunar infarctions, and infection complications can occur in patients with HIES. ${ }^{9}$ From the disease course perspective, the multiple lesions detected by MRI were more likely linked to the CMV infection and not to HIES itself, as supported by the signal alteration patterns identified.

Definitive therapy with hematopoietic stem cell transplantation has been recommended to manage HIES due to DOCK 8 mutation ${ }^{10}$; however, this therapy was not applicable for this patient because of his diagnostic delay and severe infection complications. Some lessons were learned from this case, including that an early diagnosis of HIES could promote effective treatment and improved prognosis in addition to preventing subsequent infection risks. In addition, recurrent rash, high levels of eosinophils and $\mathrm{IgE}$, and immunodeficiency are vital indicators of a HIES diagnosis.

\section{Study funding}

This study was funded by the National Natural Science Foundation of China (81801056) and the Natural Science Foundation of Zhejiang Province (LQ19H090006).

\section{Disclosure}

The authors report no disclosures relevant to the manuscript. Go to Neurology.org/N for full disclosures.

Appendix Authors

\begin{tabular}{|c|c|c|c|}
\hline Name & Location & Role & Contribution \\
\hline $\begin{array}{l}\text { Qing Ke, } \\
\text { MD, PhD }\end{array}$ & $\begin{array}{l}\text { Fahzu, } \\
\text { Hangzhou }\end{array}$ & Author & $\begin{array}{l}\text { Collection, analysis and } \\
\text { interpretation of data, } \\
\text { drafting and revising the } \\
\text { manuscript for content }\end{array}$ \\
\hline $\begin{array}{l}\text { Xiaoyan } \\
\text { Liu, MD }\end{array}$ & $\begin{array}{l}\text { Fahzu, } \\
\text { Hangzhou }\end{array}$ & Author & $\begin{array}{l}\text { Collection, analysis and } \\
\text { interpretation of data, } \\
\text { drafting and revising the } \\
\text { manuscript for content }\end{array}$ \\
\hline $\begin{array}{l}\text { Kang } \\
\text { Wang, } \\
\text { MD, PhD }\end{array}$ & $\begin{array}{l}\text { Fahzu, } \\
\text { Hangzhou }\end{array}$ & Author & $\begin{array}{l}\text { Analysis and interpretation of } \\
\text { data }\end{array}$ \\
\hline $\begin{array}{l}\text { Zhongqin } \\
\text { Chen, MD }\end{array}$ & $\begin{array}{l}\text { Fahzu, } \\
\text { Hangzhou }\end{array}$ & Author & Collection of data \\
\hline $\begin{array}{l}\text { Ming Liu, } \\
\text { MS }\end{array}$ & $\begin{array}{l}\text { Shulan } \\
\text { (Hangzhou) } \\
\text { Hospital, } \\
\text { Hangzhou }\end{array}$ & Author & Collection of data \\
\hline
\end{tabular}

Continued 
Appendix (continued)

\begin{tabular}{llll}
\hline Name & Location & Role & Contribution \\
\hline $\begin{array}{l}\text { Xiaohua } \\
\text { Ma, BS }\end{array}$ & Korla Hospital & Author & Collection of data \\
\hline $\begin{array}{l}\text { Lihua Yu, } \\
\text { MD, PhD }\end{array}$ & Fahzu, & Author & Collection of data \\
\hline $\begin{array}{l}\text { Benyan } \\
\text { Luo, MD, } \\
\text { PhD }\end{array}$ & Fahzu, & Author & $\begin{array}{l}\text { Revising the manuscript for } \\
\text { content }\end{array}$ \\
\hline
\end{tabular}

\section{References}

1. Fowler KB, Boppana SB. Congenital cytomegalovirus (CMV) infection and hearing deficit. J Clin Virol 2006;35:226-231.
2. Picard C, Bobby Gaspar H, Al-Herz W, et al. International union of immunological societies: 2017 primary immunodeficiency diseases committee report on inborn errors of immunity. J Clin Immunol 2018;38:96-128.

3. Hashemi H, Mohebbi M, Mehravaran S, Mazloumi M, Jahanbani-Ardakani H, Abtahi SH. Hyperimmunoglobulin E syndrome: genetics, immunopathogenesis, clinical findings, and treatment modalities. J Res Med Sci 2017;22:53.

4. Zhang Q, Davis JC, Lamborn IT, et al. Combined immunodeficiency associated with DOCK8 mutations. N Engl J Med 2009;361:2046-2055.

5. Alsum Z, Hawwari A, Alsmadi O, et al. Clinical, immunological and molecular characterization of DOCK8 and DOCK8-like deficient patients: single center experience of twenty-five patients. J Clin Immunol 2013;33:55-67.

6. Engelhardt KR, Gertz ME, Keles S, et al. The extended clinical phenotype of 64 patients with dedicator of cytokinesis 8 deficiency. J Allergy Clin Immunol 2015;136:402-412.

7. Cunha BA. Central nervous system infections in the compromised host: a diagnostic approach. Infect Dis Clin North Am 2001;15:567-590.

8. Metin A, Uysal G, Guven A, Unlu A, Ozturk MH. Tuberculous brain abscess in a patient with hyper IgE syndrome. Pediatr Int 2004;46:97-100.

9. Freeman AF, Collura-Burke CJ, Patronas NJ, et al. Brain abnormalities in patients with hyperimmunoglobulin E syndrome. Pediatrics 2007;119:e1121-1125.

10. Metin A, Tavil B, Azik F, et al. Successful bone marrow transplantation for DOCK8 deficient hyper IgE syndrome. Pediatr Transpl 2012;16:398-399.

\section{The AAN is at Your Side}

When you're in the office, the AAN is at your side. The AAN is your \#1 resource to support you and your care team. Whether it's resources to help you and your staff provide the best care for your patients, ensure proper reimbursement, or maximize practice performance, the AAN is at your side. Access these resources today at AAN.com/view/practiceresources.

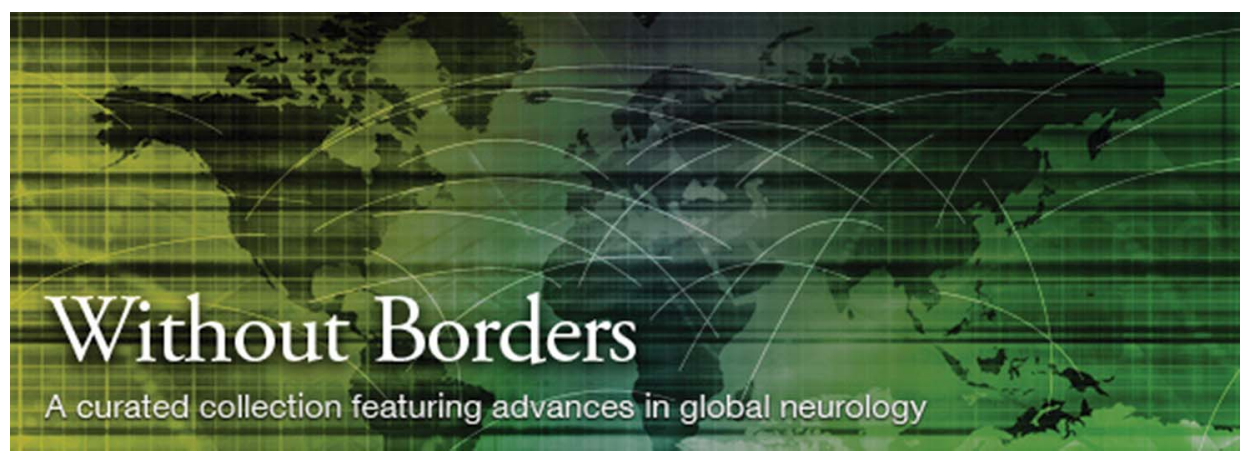

\section{Without Borders - A curated collection featuring advances in global neurology}

This Neurology ${ }^{\circledR}$ special interest website is the go-to source for tracking science and politics of neurology beyond the United States, featuring up-to-the-minute blogs, scholarly perspectives, and academic review of developments and research from Neurology journals and other sources. Curated by Gretchen L. Birbeck, MD, MPH.

Expand your world view at Neurology.org/woborders. 


\section{Neurology}

\section{Clinical Reasoning: A 16-year-old boy with progressive cognitive decline and gait impairment}

Qing Ke, Xiaoyan Liu, Kang Wang, et al.

Neurology 2020;94;449-454 Published Online before print February 28, 2020

DOI 10.1212/WNL.0000000000009062

This information is current as of February 28, 2020

\section{Updated Information \&} Services

References

Subspecialty Collections

\section{Permissions \& Licensing}

Reprints including high resolution figures, can be found at: http://n.neurology.org/content/94/10/449.full

This article cites 10 articles, 0 of which you can access for free at: http://n.neurology.org/content/94/10/449.full\#ref-list-1

This article, along with others on similar topics, appears in the following collection(s):

\section{All Cognitive Disorders/Dementia}

http://n.neurology.org/cgi/collection/all_cognitive_disorders_dementia All Genetics

http://n.neurology.org/cgi/collection/all_genetics

All Movement Disorders

http://n.neurology.org/cgi/collection/all_movement_disorders

All Neuropsychology/Behavior

http://n.neurology.org/cgi/collection/all_neuropsychology_behavior

Viral infections

http://n.neurology.org/cgi/collection/viral_infections

Information about reproducing this article in parts (figures,tables) or in its entirety can be found online at:

http://www.neurology.org/about/about_the_journal\#permissions

Information about ordering reprints can be found online:

http://n.neurology.org/subscribers/advertise

Neurology ${ }^{\circledR}$ is the official journal of the American Academy of Neurology. Published continuously since 1951, it is now a weekly with 48 issues per year. Copyright @ 2020 American Academy of Neurology. All rights reserved. Print ISSN: 0028-3878. Online ISSN: 1526-632X.

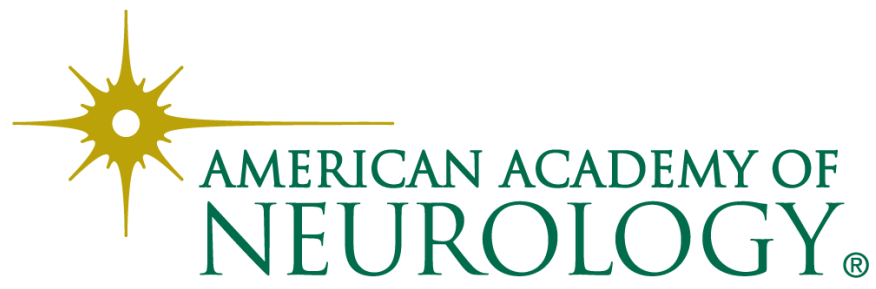

